\title{
Acta
Biochimica
Polonica
}

Vol. 48 No. $3 / 2001$

$745-754$

QUARTERLY

\section{Expression level of adenosine kinase in rat tissues. Lack of phosphate effect on the enzyme activity}

\author{
Monika Sakowicz ${ }^{1}$, Marzena Grdeń ${ }^{1}$ and Tadeusz Pawełczyk ${ }^{1,2 \bowtie}$ \\ ${ }^{1}$ Department of Molecular Medicine, Medical University of Gdańsk, ${ }^{2}$ Laboratory of Molecular \\ and Cellular Nephrology, Medical University of Gdańsk and Medical Research Center PAS, \\ Gdańsk, Poland
}

Received: 25 April, 2001; revised: 14 August, 2001; accepted: 28 August, 2001

Key words: recombinant protein, adenosine kinase, tissue distribution, phosphate, rat

In this report we describe cloning and expression of rat adenosine kinase (AK) in Esccherichaia coli cells as a fusion protein with $6 x H i s$. The recombinant protein was purified and polyclonal antibodies to AK were generated in rabbits. Immunoblot analysis of extracts obtained from various rat tissues revealed two protein bands reactive with anti-AK IgG. The apparent molecular mass of these bands was 48 and $38 \mathrm{kDa}$ in rat kidney, liver, spleen, brain, and lung. In heart and muscle the proteins that react with AK antibodies have the molecular masses of 48 and $40.5 \mathrm{kDa}$. In order to assess the relative AK mRNA level in rat tissues we used the multiplex PCR technique with $\beta$-actin mRNA as a reference. We found the highest level of AK mRNA in the liver, which decreased in the order kidney > spleen > lung > heart > brain > muscle. Measure ment of AK activity in cytosolic fractions of rat tissues showed the highest activity in the liver $(0.58 \mathrm{U} / \mathrm{g})$, which decreased in the order kidney > spleen > lung > brain > heart > skeletal muscle. Kinetic studies on recombinant AK as well as on AK in the cytosolic fraction of various rat tissues showed that this enzyme is not affected by phosphate ions.

The data presented indicate that in the rat tissues investigated at least two isoforms of adenosine kinase are expressed, and that the expression of the AK gene appears to have some degree of tissue specificity.

To date a vast number of reports has been published indicating that adenosine plays an important role in regulating many metabolic processes. It has been recognized that adeno-

\footnotetext{
This work was supported by the State Committee for Scientific Research (KBN, Poland) grants No. 4P05A11017 and 4P05A01218 to T.P.

${ }^{\circledR}$ To whom correspondence should be addressed at: Department of Molecular Medicine, Medical University of Gdańsk, ul. Dębinki 7, paw. 29, 80-211 Gdańsk, Poland; tel: (48 58) 349 2750, fax: (48 58) 349 2759, e-mail: tkpaw@amg.gda.pl

Abbreviations: ADA, adenosine deaminase; AK, adenosine kinase; 5'-NT, 5'-nucleotidase; Ni-NTA, Ni-nitrilotriacetate.
} 
sine may act as a "local hormone" in mammalian tissues showing a diversity of effects including modulation of blood flow, inflammation, neurotransmission, pain, and the endogenous response to ischemia [1-6].

The majority of basal adenosine production during normoxia is derived from the action of $S$-adenosylhomocysteine hydrolase [7, 8]. However, during enhanced oxygen demand or metabolic load, increased amounts of adenosine are formed almost exclusively from AMP by $5^{\prime}$-nucleotidase $\left(5^{\prime}-\mathrm{NT}\right)$ [9-11]. In the cell, the generated adenosine may be deaminated to inosine by adenosine deaminase (ADA), phosphorylated to AMP by adenosine kinase (AK), or transported into extracellular fluid where it exerts its effect by coupling to the A1, A2 or A3 receptors [12, 13].

A comparison of the kinetic properties of $\mathrm{AK}$ and ADA suggests that under normal conditions the majority of intracellular adenosine is metabolized by AK. It has been demonstrated that in the heart most (90\%) of the adenosine generated by cytosolic $5^{\prime}$-NT is rephosphorylated to AMP by the action of AK [14]. Thus, the activity of AK may be considered as a key point in controlling the adenosine level in the cell. Previous reports showed that the activity of $\mathrm{AK}$ is dependent on monovalent cations $\left(\mathrm{Na}^{+}, \mathrm{K}^{+}\right)$, magnesium, phosphate, arsenate and vanadate ions [15-18]. However, the effect of phosphate on AK activity remains controversial because both an activatory $[17,18]$ and an inhibitory [16] effect of $P_{i}$ have been reported. In order to extend our knowledge of AK regulatory properties we have measured the effect of phosphate on recombinant AK activity and on AK activity in the cytosolic fractions of various rat tissues.

\section{MATERIALS AND METHODS}

Pefabloc SC was from Boehringer Mannheim GmbH Biochemica (Mannheim, Germany). Leupeptin, adenosine, ATP, AMP, alkaline phosphatase-conjugated goat anti-rab- bit IgG, 5-bromo-4-chloro-3-indoyl phosphate and nitro blue tetrazolium were obtained from Sigma-Aldrich Sp. z o.o. (Poznań, Poland). Transfer membrane was from Millipore Corp. (Bedford, MA, U.S.A.). DE81 ion exchange filters were from Whatman (Maidstone, Kent, England). [U- ${ }^{14} \mathrm{C}$ ]adenosine $(20 \mathrm{MBq} / \mu \mathrm{mol})$ was from Amersham Life Science (Buckinghamshire, England). All primers used were from Integrated DNA Technologies, Inc. (Coralville, IA, U.S.A.). Total RNA Prep Plus Kit was from A\&A Biotechnology (Gdańsk, Poland). Oligo(dT) and dNTPs were from Gibco BRL (Paisley, England). Moloney murine leukemia virus reverse transcriptase (MMLV-RT) was from Epicentre Technologies (Madison, WI, U.S.A.). Tth DNA polymerase, Tfl DNA polymerase and RNasin were from Promega (Madison, WI, USA). All other reagents were of analytical grade. Male Wistar rats (200-240 g) fed Altromin C 1000 diet (Altromin $\mathrm{GmbH}$, Lage, Germany) were used for all experiments. All animals had access to food and water ad libitum.

Cloning of the adenosine kinase (AK) gene. Unless otherwise indicated, the recombinant DNA methods used were those of Sambrook et al. [19]. In order to obtain cDNA for $\mathrm{AK}$ we used $\mathrm{PCR}$ reaction with the primers AK101, GTGCTGTTTCATATGGGGAATCCTCTTC (forward) and AK102A, CGCACTAGTGGATCCCTGAGTTGCTT (reverse), which introduced restriction enzyme cleavage sites (underlined) for $N d e \mathrm{I}$ and $B a m \mathrm{HI}$, respectively. The primers were based on the rat cDNA sequence (GeneBank, accession No. U57042). PCR reaction was performed in 20 $\mu$ l final volume in $50 \mathrm{mM}$ Tris/ $\mathrm{HCl}, \mathrm{pH} 7.5,20$ $\mathrm{mM}$ ammonium sulfate, $2.5 \mathrm{mM} \mathrm{MgCl}_{2}, 0.25$ $\mathrm{mM}$ dNTPs, $2.5 \mathrm{U}$ of Tfl DNA polymerase, 0.5 $\mu \mathrm{M}$ primers and $1 \mu \mathrm{g}$ of rat liver cDNA. The PCR consisted of an initial denaturation at $95^{\circ} \mathrm{C}$ for $3 \mathrm{~min}$ and 35 cycles of $45 \mathrm{~s}$ at $95^{\circ} \mathrm{C}, 60$ $\mathrm{s}$ at $61^{\circ} \mathrm{C}, 90 \mathrm{~s}$ at $72^{\circ} \mathrm{C}$, and a final extension of $10 \mathrm{~min}$ at $72^{\circ} \mathrm{C}$. The $\mathrm{AK}$ cDNA was then cut with appropriate enzymes and ligated into the unique NdeI and BamHI sites in pPROEX-1. 
The cloned cDNA was sequenced and was confirmed to be complete AK coding cDNA.

Cell growth and expression of adenosine kinase. pPROEX-AK was used for the expression of $\mathrm{AK}$ as a fusion protein with the $6 \mathrm{xHis}$ peptide at the amino-terminus. E. coli strain BL21 (DE3) was transformed with the above mentioned plasmid and colonies were grown on LB agar plates containing ampicillin (100 $\mu \mathrm{g} / \mathrm{ml}$ ). Picked colonies were grown overnight at $37^{\circ} \mathrm{C}$ in LB-ampicillin medium, and $1 \mathrm{ml}$ of this culture was inoculated into $1 \mathrm{l}$ of fresh LB medium, and incubated at $37^{\circ} \mathrm{C}$ to an absorbance of 0.8 (measured at $600 \mathrm{~nm}$ ). Cells were then cooled to the desired temperature and the expression of the 6xHis-AK protein was induced by the addition of $1 \mathrm{mM}$ IPTG. Following induction, the cells were grown for the appropriate time, and harvested by centrifugation.

Purification of adenosine kinase. All steps were done at $4^{\circ} \mathrm{C}$. Cell pellet from $1 \mathrm{l}$ culture was suspended in $40 \mathrm{ml}$ of buffer A (50 mM potassium phosphate buffer, $\mathrm{pH}$ 6.0, $0.5 \mu \mathrm{g} / \mathrm{ml}$ leupeptin, $0.2 \mathrm{mM}$ Pefablock SC), placed on powdered dry ice and sonicated. The crude cell extract was clarified by centrifugation at $50000 \times \boldsymbol{g}$ for $30 \mathrm{~min}$. Clear supernatant was passed through a $5 \mathrm{ml}$ Ni-nitrilotriacetate (Ni-NTA) column preequilibrated with buffer A containing 300 $\mathrm{mM} \mathrm{KCl} \mathrm{(buffer} \mathrm{A1).} \mathrm{The} \mathrm{column} \mathrm{was} \mathrm{washed}$ with buffer A1 containing $50 \mathrm{mM}$ imidazole until no more protein was eluted. The 6xHis-AK protein was then eluted from the column with $7 \mathrm{ml}$ of buffer A1 containing 100 $\mathrm{mM}$ imidazole. Fractions containing high protein concentration were combined, desalted on Sephadex G-25 M (Pharmacia columns PD-10) previously equilibrated with buffer B (50 mM phosphate buffer, $\mathrm{pH} 7.5,1.0 \mathrm{mM}$ dithiothreitol, $0.5 \mu \mathrm{g} / \mathrm{ml}$ leupeptin, $0.2 \mathrm{mM}$ Pefablock SC, $20 \%$ glycerol), and applied to a Mono S HR 5/5 cation exchange FPLC column equilibrated with buffer B. The column was washed with $10 \mathrm{ml}$ of buffer $\mathrm{B}$ and eluted with a linear gradient from 0 to $2 \mathrm{M} \mathrm{KCl}$ over
$20 \mathrm{ml}$. The active fractions were pooled and stored at $-20^{\circ} \mathrm{C}$.

Tissue preparation. On the day of the experiment randomly selected rats were anesthetized with pentobarbital $(40 \mathrm{mg} / \mathrm{kg}$ of body mass), and the organs of interest were removed. Half of each organ was immediately frozen in liquid nitrogen for RNA isolation. The other half was placed in ice-cold saline for cytosol preparation.

Preparation of cytosolic fractions. The appropriate tissue was homogenized in three volumes of $50 \mathrm{mM}$ Tris/ $\mathrm{HCl}, \mathrm{pH} 7.4,1 \mathrm{mM}$ $\mathrm{MgCl}_{2}, 1 \mathrm{mM}$ dithiothreitol, $0.2 \mathrm{mM}$ Pefabloc $\mathrm{SC}, 0.5 \mu \mathrm{g} / \mathrm{ml}$ leupeptin, in a glass homogenizer with a power-driven Teflon pestle. The homogenate was centrifuged at $100000 \times \boldsymbol{g}$ for $1 \mathrm{~h}$. The resulting supernatant (in $0.5 \mathrm{ml}$ portions) was stored at $-20^{\circ} \mathrm{C}$ as the cytosolic fraction.

Adenosine kinase assay. The activity of $\mathrm{AK}$ was assayed at $25^{\circ} \mathrm{C}$ by the radiochemical method as described previously [20].

Multiplex PCR. In order to assess the level of the AK gene transcript, we performed multiplex PCR with $\beta$-actin mRNA as a reference template. The reaction mixture contained 50 $\mathrm{mM}$ Tris/ $\mathrm{HCl}, \mathrm{pH}$ 9.0, $20 \mathrm{mM}$ ammonium sulfate, $300 \mathrm{ng}$ of template, $0.40 \mu \mathrm{M}$ each of the $5^{\prime}$ and $3^{\prime}$ primers, $0.375 \mathrm{mM}$ of each dNTP, $3.75 \mathrm{mM} \mathrm{MgCl}_{2}$ and $0.75 \mathrm{U}$ of Tth DNA polymerase. The PCR for $\beta$-actin and AK consisted of an initial denaturation at $95^{\circ} \mathrm{C}$ for $3 \mathrm{~min}$ and 34 cycles of $30 \mathrm{~s}$ at $95^{\circ} \mathrm{C}, 30 \mathrm{~s}$ at $58^{\circ} \mathrm{C}, 30 \mathrm{~s}$ at $72^{\circ} \mathrm{C}$, and a final extension of $10 \mathrm{~min}$ at $72^{\circ} \mathrm{C}$ amplification. For AK amplification the $\mathrm{AK} 1$ and AK2 primers were used [21]. This defines a DNA fragment of 616 base pairs. Primers for $\beta$-actin amplification were as described [21], and the product was 511 base pairs long.

The PCR reactions were performed in an Eppendorf-Mastercycler. PCR products were separated by agarose gel electrophoresis and assessed by quantitation of ethidium bromide-stained bands with the use of the Gel Doc 2000 system (Bio-Rad). The relative 
amounts $\left(\mathrm{OD} / \mathrm{mm}^{2}\right)$ of both amplified transcripts were compared using the computer program Quantity One (Bio-Rad).

Antibodies. Polyclonal antibodies to rat adenosine kinase were generated in rabbits. Rabbits were subcutaneously injected in the back of the neck with $400 \mu \mathrm{g}$ of purified recombinant AK in Freund's adjuvant followed by three boost with $200 \mu \mathrm{g}$ of antigen each every 3 weeks. The antibodies were purified by chromatography on a protein A-agarose column.

SDS/PAGE and immunoblotting. Samples (100 $\mu \mathrm{g}$ of protein) were separated by polyacrylamide gel electrophoresis (12\% acrylamide) in the presence of sodium dodecyl sulfate (SDS/PAGE) [22] and then electrophoretically transferred to Immobilon poly(vinylidenedifluoride) (Millipore) transfer membrane. The membrane was blocked with $3 \%$ bovine albumin (fraction V) in phosphate-buffered saline $\left(\mathrm{NaCl} / \mathrm{P}_{\mathrm{i}}\right)$ with $0.02 \%$ $\mathrm{NaN}_{3}$ and then washed with $\mathrm{NaCl} / \mathrm{P}_{\mathrm{i}}$. The blocked membrane strips were incubated with rabbit anti AK polyclonal antibodies (dilution 1:10000). Immunostaining was done using alkaline phosphatase-conjugated goat antirabbit IgG (dilution 1:20000), the chromogenic substrate 5-bromo-4-chloro-3-indoyl phosphate and nitro blue tetrazolium.

Analytical. Protein concentration was determined by the method of Bradford [23] with bovine serum albumin as standard. DNA and RNA concentration was determined by measuring the absorbance at $260 \mathrm{~nm}$.

\section{RESULTS}

\section{Expression and purification of adenosine kinase}

In order to obtain large quantities of adenosine kinase protein we have cloned the cDNA of rat $\mathrm{AK}$ into the $\mathrm{pPROEX}-1$ vector, which in our hands proved to be useful in obtaining recombinant proteins in $E$. coli cells [24-26]. A high yield of the induced protein was obtained when BL21(DE3) cells were cultured at $37^{\circ} \mathrm{C}$ for $5 \mathrm{~h}$, although an even higher yield of soluble protein was obtained in cells cultured at $24^{\circ} \mathrm{C}$ for $16 \mathrm{~h}$. Therefore, expression of $6 \mathrm{xHis}-$ $\mathrm{AK}$ at $24^{\circ} \mathrm{C}$ was run routinely.

Usually the process of $6 \mathrm{xHis}-\mathrm{AK}$ purification started with $5 \mathrm{~g}$ of $E$. coli cells obtained from $1 \mathrm{l}$ of the cell culture. Soluble bacterial lysate was first subjected to chromatography on Ni-NTA. The purity and the apparent molecular mass of the eluted proteins were checked by SDS/PAGE (Fig. 1). It was found that

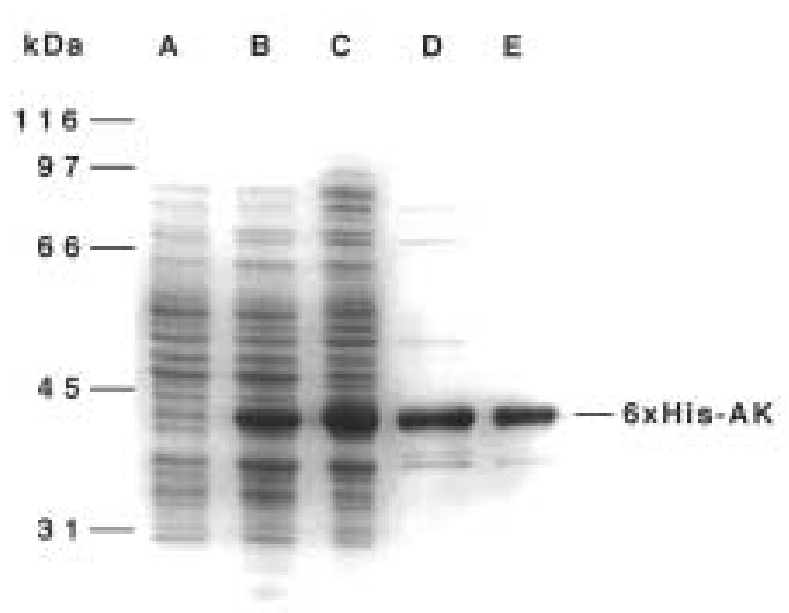

Figure 1. SDS/PAGE (12\%) of adenosine kinase expressed in $E$. coli cells.

Lane A, $50 \mu \mathrm{g}$ of $E$. coli cells lysate (not induced); lane B, $50 \mu \mathrm{g}$ of lysate of $E$. coli cells induced for $16 \mathrm{~h}$ at $23^{\circ} \mathrm{C}$; lane C, $50 \mu \mathrm{g}$ of high-speed supernatant of $E$. coli cell lysate; lane D, $10 \mu \mathrm{g}$ of $6 \mathrm{xHis-AK}$ purified on Ni-NTA; lane E, $10 \mu \mathrm{g}$ of $6 \mathrm{xHis}-\mathrm{AK}$ purified on Mono $\mathrm{S}$ column. Positions of the molecular mass markers are indicated on the left.

6xHis-AK was purified to near homogeneity by this step. However, some proteins with higher molecular masses as well as degradation products were visible. Subsequent chromatography on a cation exchange (Mono S) column gave further improvement in the purity of 6xHis-AK. Pure 6xHis-AK migrated on $12 \%$ SDS/PAGE as a protein with a molecular mass of $41 \mathrm{kDa}$ (Fig. 1). This is in good agreement with $41.5 \mathrm{kDa}$ calculated from the 
Table 1. Purification of recombinant rat adenosine kinase.

The purification started with $5 \mathrm{~g}$ of $E$. coli cells obtained from $1 \mathrm{l}$ of $16 \mathrm{~h}$ cell culture grown at $23^{\circ} \mathrm{C}$. AK was assayed as described under Materials and Methods with $1 \mu \mathrm{M}$ adenosine. Data presented are representative of those obtained in five separate purifications.

\begin{tabular}{lcccc}
\hline Step & $\begin{array}{c}\text { Protein } \\
(\mathrm{mg})\end{array}$ & $\begin{array}{c}\text { Total activity } \\
\text { (nmol/min) }\end{array}$ & $\begin{array}{c}\text { Specific activity } \\
\text { (nmol/min per mg) }\end{array}$ & $\begin{array}{c}\text { Yield } \\
(\%)\end{array}$ \\
\hline E. coli extract (supernatnat) & 994 & 1612 & 1.62 & 100 \\
Ni-NTA & 10.1 & 302 & 29.9 & 19 \\
MonoS & 8.04 & 285.2 & 35.47 & 18 \\
\hline
\end{tabular}

amino-acid sequence of the recombinant protein. Typical data obtained from purification steps are summarized in Table 1.

\section{Effect of phosphate ions on adenosine kinase activity}

Several previous reports indicated that the activity of $\mathrm{AK}$ is affected by monovalent cations $\left(\mathrm{K}^{+}, \mathrm{Na}^{+}\right)$, magnesium, phosphate and other polivalent ions [15-18]. Our experiments with the recombinant rat enzyme showed that phosphate ions do not affected either the $K_{\mathrm{m}}(1.2 \mu \mathrm{M})$ for adenosine or the enzyme $V_{\max }$ (Fig. 2). The lack of the phosphate effect on AK activity was observed in the range of 0.1-50 mM. No effect of $\mathrm{P}_{\mathrm{i}}$ on $\mathrm{AK}$ activity was observed at various concentrations of ATP and $\mathrm{MgCl}_{2}$ (not shown). A change in the $\mathrm{pH}$ of the reaction mixture from 7.4 to 6.0 was not associated with an alteration of $\mathrm{AK}$ sensitivity to $\mathrm{P}_{\mathrm{i}}$ (not shown). The effect of phosphate ions was also tested on AK activity in the cytosol obtained from several rat tissues. Each cytosols preparation was deprived of low molecular mass molecules by chromatography on Sephadex G-25 equilibrated with the extraction buffer, which does not contain phosphate ions. Measurements of AK activity in the presence and absence of $10 \mathrm{mM} \mathrm{P}_{i}$ showed that phosphate ions do not affect the enzyme activity in the cytosol of rat liver, kidney, spleen, lung, brain, heart and skeletal muscle (Table 2).

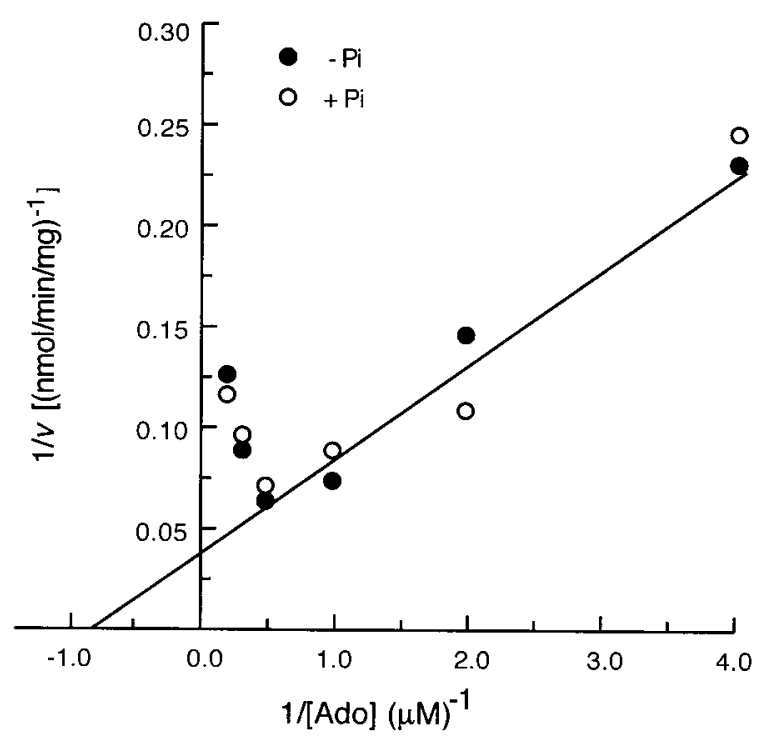

Figure 2. Effect of phosphate on the activity of recombinant adenosine kinase.

The activity of AK was assayed as described under Materials and Methods in $50 \mathrm{mM}$ Hepes/NaOH, $\mathrm{pH} 7.2$, $100 \mathrm{mM} \mathrm{KCl}, 1.0 \mathrm{mM} \mathrm{MgCl}_{2}, 1 \mathrm{mM}$ ATP. The open and closed symbols represent data obtained in the presence and absence of $10 \mathrm{mM} \mathrm{P}_{i}$, respectively. The average standard deviation for all points in the presence and absence of $P_{i}$ was within $4-7 \%$ and $3-8 \%$, respectively $(n=4)$.

\section{Expression level of adenosine kinase in rat tissues}

Immunoblot analysis showed that all rat tissues examined contained at least two protein band reactive with anti-AK IgG (Fig. 3). The apparent molecular mass of these proteins 
was 48 (AK1) and 38 (AK3) kDa in rat kidney, liver, spleen, brain and lung. In heart and muscle the proteins that reacted with $\mathrm{AK}$ antibodies have molecular masses of 48 (AK1) and ney and spleen there was a good correlation between AK activity and the protein and mRNA levels. The level of AK mRNA correlated only partially with the activity and pro-

Table 2. The effect of phosphate ions on adenosine kinase in the cytosol of various rat tissues.

The activity of AK was assayed as described under Materials and Methods with $1 \mu \mathrm{M}$ adenosine. The data are mean \pm S.D. $(n=7)$.

\begin{tabular}{lll}
\hline Tissue & \multicolumn{2}{l}{ Specific activity $(\mathrm{nmol} / \mathrm{min}$ per $\mathrm{mg}$ protein) } \\
& $-\mathrm{P}_{\mathrm{i}}$ & $+10 \mathrm{~nm}_{\mathrm{i}}$ \\
\hline Liver & $0.579 \pm 0.019$ & $0.563 \pm 0.006$ \\
Kidney & $0.376 \pm 0.017$ & $0.358 \pm 0.11$ \\
Spleen & $0.346 \pm 0.014$ & $0.339 \pm 0.013$ \\
Lung & $0.173 \pm 0.014$ & $0.179 \pm 0.008$ \\
Brain & $0.081 \pm 0.003$ & $0.094 \pm 0.005$ \\
Heart & $0.075 \pm 0.003$ & $0.071 \pm 0.004$ \\
Skeletal muscle & $0.027 \pm 0.006$ & $0.021 \pm 0.004$ \\
\hline
\end{tabular}

40.5 (AK2) kDa. The highest level of the AK3 protein was found in the liver, which decreased in the order kidney $>$ spleen $>$ brain $>$ lung (Fig. 3B). In all tissues examined the level of the AK1 protein was similar except for skeletal muscle where it was 5 -fold higher. The only tissues where the AK2 protein was detected were heart and skeletal muscle. The level of the AK2 protein in skeletal muscle exceeds 5-fold that in the heart (Fig. 3B).

In order to evaluate the level of mRNA for adenosine kinase in rat tissues we performed multiplex RT-PCR. As a reference transcript, we amplified a fragment (511 bp) of $\beta$-actin. The data presented in Fig. 4 indicate that kidney and liver contained similar and highest level of AK mRNA. Heart, lung and spleen contained similar levels (about $50 \%$ of that found in the liver) of AK mRNA. The lowest level of AK mRNA was found in the brain and skeletal muscle. A comparison of the relative level of AK mRNA, protein and activity indicated that the expression level of adenosine kinase was highest in the liver and decreased in the order kidney > spleen > lung > heart > brain $>$ skeletal muscle (Fig. 5). In liver, kid- tein level in lung, heart and brain. In skeletal muscles the level of the AK protein was unproportionally high comparing the level of mRNA and AK activity.

\section{DISCUSSION}

The system for expression of rat AK in $E$. coli cells presented in this report makes it possible to obtain high quantities of active enzyme. From $1 \mathrm{l}$ of $16 \mathrm{~h} E$. coli culture $8 \mathrm{mg}$ of pure enzyme was obtained by a two step purification procedure (Table 1). The existence of two isoforms of AK mRNA in rats and humans was reported previously, and the human isoforms were cloned and expressed in $E$. coli [27]. The sequence-derived molecular mass of these two rat AK isoforms are 38.5 and 41.4 $\mathrm{kDa}$. In our experiments we have cloned the short (38.5 kDa) isoform of AK. Purified recombinant AK displayed similar kinetic properties to those observed in various mammalian tissues [17, 21, 27, 28]. The activity of the obtained enzyme exhibited substrate inhibition by adenosine and a dependence on the 
A

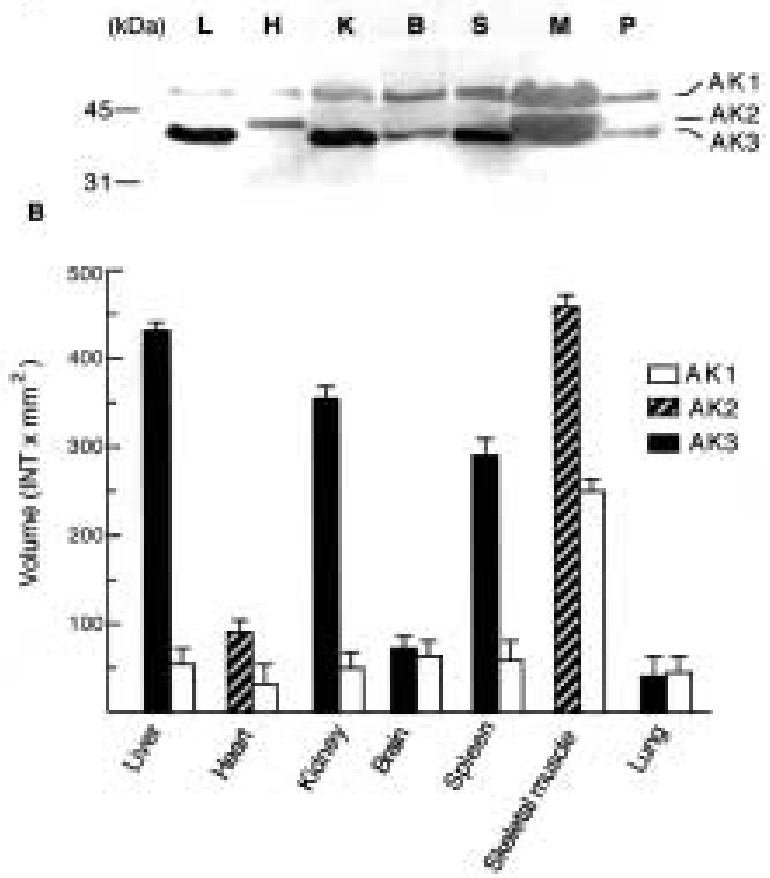

Figure 3. Protein level of adenosine kinase in tissues of diabetic rats.

Cytosolic fractions $(100 \mu \mathrm{g})$ of the tissues examined were subjected to SDS/PAGE (12\%) and transferred to Immobilon membrane as described under Materials and Methods. The membranes were immunobloted with anti-AK IgG. A. Lanes L, H, K, B, S, M, and P refer to the cytosolic fractions of rat liver, heart, kidney, brain, spleen, muscle, and lung, respectively. The presented blot is representative of those performed on tissue extracts obtained from five different animals. The bands with apparent molecular masses of $48,40.5$ and $38 \mathrm{kDa}$ are marked as AK1, AK2 and AK3, respectively. B. The blot shown in part A was scanned and the bands were quantitated with the use of the Gel Doc 2000 system and the computer program Quantity One. The program calculated area of the analyzed bands by summing the intensities of the pixels within the band boundary and multiplying by pixel area. The obtained value was adjusted for background intensity and expressed in arbitrary intensity units $\times \mathrm{mm}^{2}$ (INT $\mathrm{x}$ $\mathrm{mm}^{2}$ ). Data are means of three separate quantitation \pm S.D.

presence of ATP and $\mathrm{Mg}^{2+}$, but not phosphate ions (Fig. 2). Experiments performed by Maj et al. [17] on Chinese hamster ovary recombinant $\mathrm{AK}$ and purified $\mathrm{AK}$ from beef liver showed that $\mathrm{AK}$ is activated by $\mathrm{P}_{\mathrm{i}}$. They proposed that the $P_{i}$ effect on $A K$ is to protect the enzyme from inactivation at high adenosine
A

B
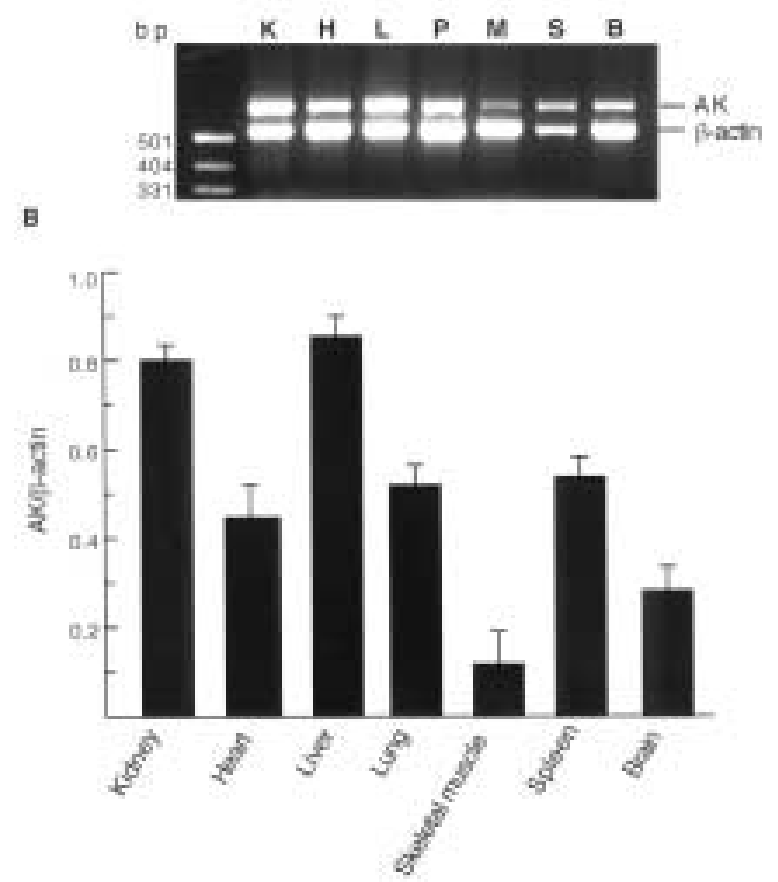

Figure 4. Level of adenosine kinase gene transcript in rat tissues.

The AK mRNA level was assessed by quantitation of multiplex RT-PCR products as described under Materials and Methods. A. Multiplex RT-PCR products separated by $2 \%$ agarose gel electrophoresis. Lanes $\mathrm{K}, \mathrm{H}, \mathrm{L}$, $\mathrm{P}, \mathrm{M}, \mathrm{S}$, and B refer to the PCR products obtained for kidney, heart, liver, lung, muscle, spleen and brain, respectively. The gel shown is representative of those obtained for five rats. B. Multiplex RT-PCR products were assessed by quantitation of ethidium bromide-stained bands with the use of the Gel Doc 2000 system and the computer program Quantity One. The ratio of AK PCR product $\left(\mathrm{OD} / \mathrm{mm}^{2}\right)$ to $\beta$-actin PCR product was calculated $(\mathrm{AK} / \beta$-actin). The data are mean \pm S.D. $(\mathrm{n}=5)$.

concentration and decreased $\mathrm{pH}$ or to stabilize substrate binding at the active site. Our experiments showed that neither the activity of recombinant $\mathrm{AK}$ nor the activity of $\mathrm{AK}$ in the cytosolic fractions from various rat tissues is affected by phosphate ions. The reason for such a discrepancy between our results and those reported by Maj et al. [17] are unknown.

Adenosine kinase is found almost in all mammalian cells. We found that rat liver had the highest AK activity, which decreased in the order kidney > spleen > lung > brain > 
heart > skeletal muscle (Table 2). Similar results for rat tissues were reported previously [29]. In human tissues almost equivalent levels of AK activity were found in liver, kidney, brain cortex and pancreas [30]. The immunoblot analysis of various rat tissues performed with the use of our anti-AK IgG showed three distinct protein bands with the apparent molecular masses of 38, 40.5, and $48 \mathrm{kDa}$ (Fig. 3). As was mentioned above, in rats the presence

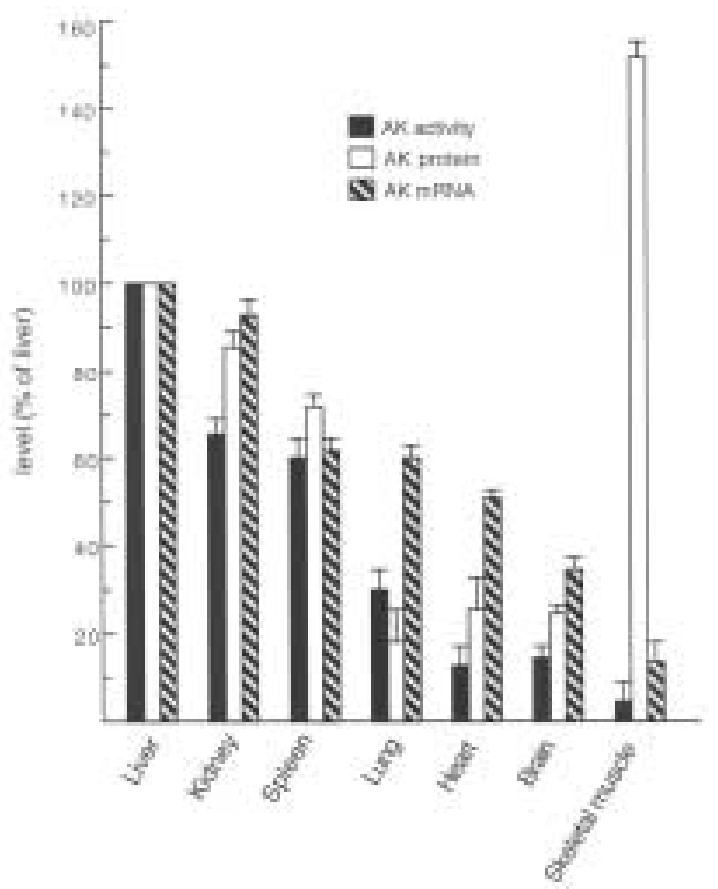

Figure 5. Relative levels of adenosine kinase activity, protein and mRNA in rat tissues.

The activity of AK was assayed as described under Materials and Methods. The AK protein (AK1+AK2+AK3) content was assessed by quantitation of Western blots as described in Fig. 3. The level of AK mRNA was evaluated by performing multiplex RT-PCR and quantitation of ethidium bromide-stained bands as described under Materials and Methods. The data are presented as a percentage of the value found in the liver and are means of the analyses performed on tissues obtained from five rats \pm S.D.

of two AK isoforms with molecular masses of 38.5 and $41.4 \mathrm{kDa}$ was deduced based on cDNA sequence [27]. The nature of the $48 \mathrm{kDa}$ protein is unknown because to date such adenosine kinase has not been cloned or isolated from any tissue. The work on cloning and identifying this protein is under way in our laboratory. Our data indicate that the 48 $\mathrm{kDa}$ protein binds to a $5^{\prime}$-AMP-Sepharose column and is eluted by adenosine (not shown). A similar observation was made by Singh et $a l$. [31] for Syrian hamster liver cell extract. A clue indicating that the $48 \mathrm{kDa}$ protein might be another isoform of $\mathrm{AK}$ is the report of Chang et al. [32] who isolated and purified AK with a molecular mass of $56 \mathrm{kDa}$ from murine leukemia cells.

In order to asses the AK mRNA level in rat tissues we performed multiplex RT-PCR with $\beta$-actin as reference template. Densitometric analysis of PCR products separated by agarose gel electrophoresis showed similar levels of AK mRNA in liver and kidney, an intermediate level in the heart, lung and spleen, and significantly lower levels in brain and muscle. In humans the level of AK mRNA was reported to be intermediate in the heart and low in brain and lung [33]. The cDNA fragment chosen by us for amplification was common for both the AK2 and AK3 isoforms of AK. A comparison of the cDNA sequence for AK3 and AK2 showed 100\% identity following bases 105 and 113, respectively [27]. There is no rationale to exclude the existence of other isoforms of $\mathrm{AK}$ (including the $48 \mathrm{kDa}$ protein) produced by differential splicing. Thus, it should be kept in mind that the product of our multiplex PCR could be generated on two or more kinds of AK templates. We found that the AK mRNA level correlated partially with AK activity and protein level in the analyzed rat tissues except for skeletal muscles, where the protein level was unproportionally high (Fig. 5). The reason for such a deviation is unclear, but it might be a result of differences in protein synthesis and degradation and/or differences in $\mathrm{AK}$ gene expression and mRNA stability. On the other hand, the activity of AK in muscle was only $5 \%$ of that found in the liver, whereas the level of the protein that immunoreacted with anti-AK IgG was 1.5 -fold higher than in the liver. If one assumes that the protein band detected in muscle cytosol by 
our immunoblots corresponded to native AK it might be speculated that the regulation of AK activity in skeletal muscle involves some unknown factors, which are generated in muscle cells under conditions requiring a rapid increase in the enzyme activity.

In summary, the results presented have indicate that the activity of rat AK is not affected by phosphate ions and that the expression of the AK gene in rats appears to have some degree of tissue specificity. The presence in the skeletal muscle of high level of the AK protein which is inactive under standard assay conditions remains to be examined, as well as the nature of the $48 \mathrm{kDa}$ protein immunoreactive with anti-AK IgG that was detected in all rat tissues examined.

\section{R E F E R E N C E S}

1. Williams, M. \& Burnstock, G. (1997) Purinergic neurotransmission and neuromodulation: A historical perspective; in Purinergic Approaches in Experimental Therapeutics (Jacobson, K.A. \& Jarvis, M.F., eds.) pp. 3-26, Wiley-Liss, New York.

2. Berne, R.M. (1980) The role of adenosine in the regulation of coronary blood flow. Circ. Res. 47, 807-813.

3. Cronstein, B.N. (1994) Adenosine, an edogenous anti-inflammatory agent. J. Appl. Physiol. 76, 5-13.

4. Schubert, P., Rudolphi, K.A., Fredholm, B.B. \& Nakamura, Y. (1994) Modulation of nerve and glial function by adenosine - role in the development of ischemic damage. Int. $J$. Biochem. 26, 1227-1236.

5. Cohen, M.V., Walsh, R.S., Goto, M. \& Downey, J.M. (1995) Hypoxia preconditions rabbit myocardium via adenosine and catecholamine release. J. Mol. Cell Cardiol. 27, 1527-1534.

6. Rudolphi, K.A. \& Schubert, P. (1997) Modulation of neuronal and glial cell function by adenosine and neuroprotection in vascular dementia. Behav. Brain Res. 83, 123-128.

7. Lloyd, H.G., Deussen, A., Wuppermann, H. \& Schrader, J. (1988) The transmethylation pathway as a source for adenosine in the isolated guinea-pig heart. Biochem. J. 252, 489-494.

8. Bontemps, F., Vincent, M.F. \& Van den Berghe, G. (1993) Mechanism of elevation of adenosine levels in anoxic hepatocytes. Biochem. J. 290, 671-677.

9. Headrick, J.P., Emerson, C.S., Berr, S.S., Berne, R.M. \& Matherne, G.P. (1996) Interstitial adenosine and cellular metabolism during beta-adrenergic stimulation of the in situ rabbit heart. Cardiovasc. Res. 31, 699-710.

10. Spielman, W.S. \& Arend, L.J. (1991) Adenosine receptors and signaling in the kidney. $H y$ pertension 17, 117-130.

11. Lowenstein, J.M., Yu, M.-K. \& Narto, Y. (1983) Regulation of adenosine metabolism by 5 '-nucleotidase; in Regulatory Function of Adenosine (Berne, R.M., Rall, T.W. \& Rubio, R., eds.) pp. 117-131, Martinus Nijhoff Publishing, Boston.

12. Stiles, G.L. (1992) Adenosine receptors. J. Biol. Chem. 267, 6451-6454.

13. Zhou, Q.-Y., Li, C., Olah, M.E., Johnson, R.A., Stiles, G.L. \& Civelli, O. (1992) Molecular cloning and characterization of a novel adenosine receptor: The A3 adenosine receptor. Proc. Natl. Acad. Sci. U.S.A. 89, 7432-7436.

14. Kroll, K., Decking, U.K.M., Dreikorn, K. \& Schrader, J. (1993) Rapid turnover of the AMP-adenosine metabolic cycle in the guinea pig heart. Circ. Res. 73, 846-856.

15. Fisher, M. \& Newsholme, E.A. (1984) Properties of rat heart adenosine kinase. Biochem. J. 221, 521-528.

16. Gorman, M., He, M-X., Hall, C.S. \& Sparks, H.V. (1997) Inorganic phosphate as regulator 
of adenosine formation in isolated guinea pig hearts. Am. J. Physiol. 272, H913-H920.

17. Maj, M.C., Singh, B. \& Gupta, R.S. (2000) The influence of inorganic phosphate on the activity of adenosine kinase. Biochim. Biophys. Acta 1476, 33-42.

18. Hao, W. \& Gupta, R.S. (1996) Pentavalent ions dependency of mammalian adenosine kinase. Mol. Biol. Int. 38, 889-899.

19. Sambrook, J., Fritsch, E.F. \& Maniatis, F. (1989) Molecular Cloning: A Laboratory Manual, 2nd edn., Cold Spirng Harbor Laboratory Press, Cold Spring Harbor, NY.

20. Pawelczyk, T., Bizon, D. \& Angielski, S. (1992) The distribution of enzymes involved in purine metabolism in rat kidney. Biochim. Biophys. Acta 1116, 309-314.

21. Pawelczyk, T., Sakowicz, M., SzczepanskaKonkel, M. \& Angielski, S. (2000) Decreased expression of adenosine kinase in streptozotocin-induced diabetes mellitus rats. Arch. Biochem. Biophys. 375, 1-6.

22. Laemmli, U.K. (1970) Cleavage of structural proteins during the assembly of the head of bacteriophage T4. Nature 227, 680-685.

23. Bradford, M.M. (1976) A rapid and sensitive method for the quantitation of microgram quantities of protein utilizing the principle of protein-dye binding. Anal. Biochem. 72, 248-254.

24. Matecki, A., Stopa, M., Was, A. \& Pawelczyk, T. (1997) Effect of sphingomyelin and its metabolites on the activity of human recombinant PLC d1. Int. J. Biochem. Cell Biol. 29, 815-828.

25. Pawełczyk, T. \& Matecki, A. (1997) Expression, purification and kinetic properties of human recombinant phospholipase C $\delta 3$. Acta Biochim. Polon. 44, 221-230.

26. Pawelczyk, T., Kowara, R., Golebiowski, F. \& Matecki, A. (2000) Expression in Escherichia coli and simple purification of human Fhit protein. Protein Expr. Purif. 18, 320-326.

27. McNally, T., Helfrich, R.J., Cowart, M., Dorwin, S.A., Meuth, J.L., Idler, K.B., Klute, K.A., Simmer, R.L., Kowaluk, E.A. \& Halbert, D.N. (1997) Cloning and expression of the adenosine kinase gene from rat and human tissues. Biochem. Biophys. Res. Commun. 231, 645-650.

28. Mimouni, M., Bontemps, F. \& Van den Berghe, G. (1994) Kinetic studies of rat liver adenosine kinase. Explanation of exchange reaction between adenosine and AMP. J. Biol. Chem. 269, 17820-17825.

29. Jackson, R.C., Morris, H.P. \& Weber, G. (1978) Adenosine deaminase and adenosine kinase in rat hepatomas and kidney tumors. Brit. J. Cancer 37, 701-713.

30. Bhalla, K., Nayak, R. \& Grant, S. (1984) Isolation and characterization of a deoxycytidine kinase-deficient human promyelocytic leukemic cell line highly resistant to 1-beta-D-arabinofuranosylcytosine. Cancer Res. 44, 50295037.

31. Singh, B., Hao, W., Wu, Z., Eigl, B. \& Gupta, R.S. (1996) Cloning and characterization of cDNA for adenosine kinase from mammalian (Chinese hamster, mouse, human and rat) species. High frequency mutants of Chinese hamster ovary cells involve structural alterations in the gene. Eur. J. Biochem. 241, 564-571.

32. Chang, C.-H., Brockman, R.W. \& Bennett, L.L. (1980) Adenosine kinase from L1210 cells. Purification and some properties of the enzyme. J. Biol. Chem. 255, 2366-2371.

33. Spychala, J., Datta, S.N., Takabayashi, K., Datta, M., Fox, I.H., Gribbin, T. \& Mitchell, B.S. (1996) Cloning of human adenosine kinase cDNA: Sequence similarity to microbial ribo- and fructokinases. Proc. Natl. Acad. Sci. U.S.A. 93, 1232-1237. 